PRODUCTION

ENGINEERING

ARCHIVES
2016, Vol. 10, No 1, pp 17-20

ISSN 2353-5156 (print version)

ISSN 2353-7779 (online version)

\title{
Problems concerning product quality enhancement
}

\author{
Marek Krynke ${ }^{1}$, Krzysztof Mielczarek ${ }^{2}$ \\ ${ }^{1}$ Institute of Production Engineering, Faculty of Management, Czestochowa University of Technology, Armii Krajowej 19B, \\ 42-201 Czestochowa, Poland, e-mail: krynke@zim.pcz.pl \\ ${ }^{2}$ Institute of Production Engineering, Faculty of Management, Czestochowa University of Technology, Armii Krajowej 19B, \\ 42-201 Czestochowa, Poland, e-mail: mielczarek@zim.pcz.pl
}

\begin{abstract}
In the article analysis of the discrepancies in the production process for selected products in a company producing candles was carried out. Using the Pareto-Lorenzdiagram and the FMEA method the most essential areas having influence on the production of candles were shown. Apart from factors connected with the manufacturing side of the process, factors of the labour organization and requirements concerning the quality of material were also noted. An appropriate quality of equipment constitutes one of the essential conditions of production process functioning and this directly influences manufacturing possibilities of the enterprise. A synthesis of immaterial factors that influence the production of the enterprise, taking into consideration conditions of functioning the production system, was also carried out. The set of factors selected for description was the fourteenth Toyota management principle. Respondents were asked to provide answers which could bring the best improvements.
\end{abstract}

Key words - FMEA method,Pareto-Lorenz diagram, BOST analysis, Toyota Principles, quality, candles production

\section{Introduction}

Modern technological processes should be characterized by a high rate of production, reproducibility and repeatability and stability of individual technological operations. These features influence the requirements for individual process steps. Careful discernment about the suitable quality of the products is undoubtedly a complex process because of the multiplicity of factors determining it. The basic variables that affect the quality of the product are: (MIELCZAREK K., MAZUR M. 2007):

- quality of the material,

- quality of the process,

- quality of the equipment,

- quality of staff,
- quality of the environment,

- quality of the measurement.

All variables globally create a high quality of the final product, and therefore should be considered together, not forgetting that each of the components is the result of the impact of the following variables in every aspect of production (BORKOWSKI S., KRYNKE M., INGALDI M. 2012).

The quality of the process depends largely on the methods and techniques used to implement the individual technological operations on time. In addition to factors directly linked to the party manufacturing processes are also important factors of work organization and quality requirements of the material. Suitable quality equipment is also significant. It is one of the basic conditions for the functioning of production lines and 
directly affects the production capacity of the company (Vogt K., KuJAwiŃSKA A.2013).

\section{Structure of discrepancies for chosen products}

During manufacturing, product deviation causes withdrawal from sale. For the purpose of investigating this situation analysis of the discrepancies was carried out with the use of the Pareto-Lorenzdiagram. The following types of products was analysed: removable tube votive candle.

These products are produced on extruding press and injection moulding machines. Discrepancies that turned up during the production are introduced in table 1 .

Table 1. Types of discrepancies in the production of removable tube votive candle

\begin{tabular}{|l|l|}
\hline Discrepancy symbol & Name of discrepancy \\
\hline $\mathrm{N}_{1}$ & cut structure \\
\hline $\mathrm{N}_{2}$ & too thin \\
\hline $\mathrm{N}_{3}$ & jagged edges \\
\hline $\mathrm{N}_{4}$ & too thick \\
\hline $\mathrm{N}_{5}$ & dirty surface \\
\hline $\mathrm{N}_{6}$ & wrong color \\
\hline
\end{tabular}

Source: own study

In Fig. 1 Pareto-Lorenz diagram is presented. The Pareto chart shows, in descending order, the relative share of each element in the overall effect. This method has been applied to demonstrate the participation of each element in the area, and then to arrange all elements according to their level of significance. It shows the structure of the discrepancies and their participation in an analysed 30 day research period. It results from the data analysis that the most often appearing discrepancies there is cut structure produced on extruding press. The discrepancies connected with the inappropriate thickness of the product wall were also often revealed.

In order to prevent the occurrence of the discrepancies in the sheet die, it is necessary to apply the technology of the extruder slit through the use of selfcleaning grid on which dirt settles (for example, grains of sand) present in the granules. Elimination of discrepancy associated with inadequate wall thickness of the tube is possible by adjusting the modernization of the extruder and the exact adjustment of the machine. In the case of the production removable tube votive candle elimination of discrepancies $\mathrm{N}_{1}, \mathrm{~N}_{2}, \mathrm{~N}_{3}$ that are caused by the cut structure, too thin structure and jagged edges of the tube, the number of defective products will be reduced by about $71 \%$.

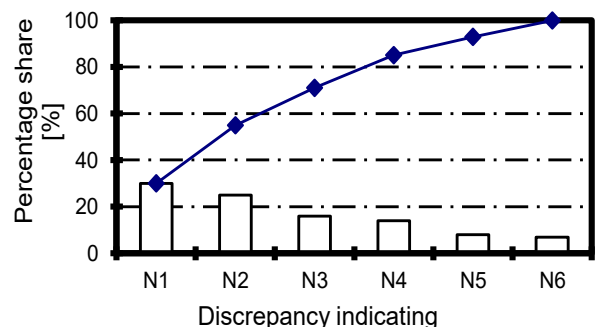

Fig. 1. Pareto-Lorenz diagram for discrepancyof removable tube votive candle

Source: own study

\section{Analysis of the causes and conse- quences of any nonconformity}

The analysis of the causes and effects of noncompliance in the selected products was introduced using the FMEA method. Failure modes and effects analysis (FMEA) is a step-by-step approach for identifying all possible failures in a design, a manufacturing or assembly process, or a product or service. A successful FMEA activity helps to identify potential failure modes based on experience with similar products and processes or based on common physics of failure logic. Effects analysis refers to studying the consequences of those failures on different system levels (KNOP K., SELEJDAK J. 2009).

Fig.2 presents a summary RPNthat was analyzed for the analyzed product. The results show that the highest value of the risk priority is for discrepancy: cut of element structure. RPN acceptable level exceeds the mismatch caused by jagged edges of the product (Ulewicz R. 2003). For the customer, such goods are without value that should take corrective action to eliminate these problems. Steps that should be taken in order to reduce the risk of extinction of this discrepancy is the modernization of the extrusion head by mounting the mesh on which the deposit will be getting any contamination with the pellet plasticizing zone. On the other hand, to eliminate the discrepancy caused by the occurrence of jagged edges after cutting the upper waste cutting blades should be replaced or properly sharpened and repeating this step each time the occurrence of the discrepancy. 


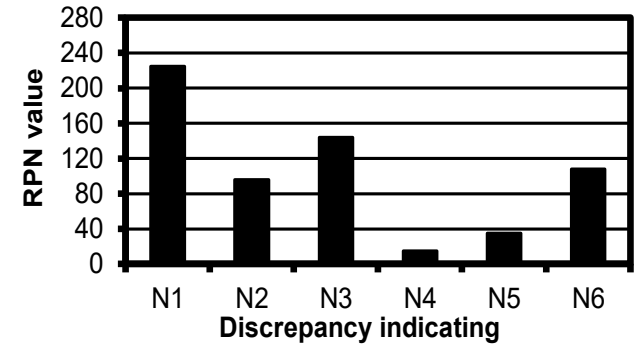

Fig. 2. Summary combination of RPN for discrepancy: removable tube votive candle.

Source: own study.

\section{Analysis of areas for improvement of company based on the fourteenth Toyota management principle}

The fourteenth principle encourages continual reflection and continuous improvement (BORKOWSKI S. 2012a). According to this principle it is crucial to determine the causes of a problem by solving technical issues. Continuous improvement of the process and production is extremely significant for a company which has been functioning on the market for many years. The study examines the factors that describe the fourteenth Toyota management principle contained in the E8area BOST survey conducted among production workers. Respondents were asked to provide answers to the following question (BORKOWSKI S. 2012b): Decide with the use of the scale 1-10 (10 the most important factor) which area can bring the best effects after being improved? Table 2 presents a percentage significance list rates for factors belonging to area E8.

Table 2. Principle 14. Evaluation structure [\%] of the factors' importance for E8 area.

\begin{tabular}{|c|c|c|c|c|c|c|c|c|c|c|}
\hline \multirow{2}{*}{ Evaluation } & \multicolumn{10}{|c|}{ Indicating the factors } \\
\hline & ZT & SM & PT & JK & UM & RE & DA & PN & WS & WD \\
\hline 1 & 0 & 25 & $\boldsymbol{O}$ & 0 & $\boldsymbol{O}$ & 15 & 60 & $\boldsymbol{O}$ & 0 & 0 \\
\hline 2 & 10 & 35 & $\boldsymbol{O}$ & 0 & $\boldsymbol{O}$ & 15 & 25 & 10 & 5 & $\boldsymbol{O}$ \\
\hline 3 & 45 & 20 & 0 & $\boldsymbol{O}$ & $\boldsymbol{O}$ & 15 & 10 & $\boldsymbol{O}$ & 5 & 5 \\
\hline 4 & 20 & 20 & 0 & 0 & 0 & 35 & 5 & 5 & 5 & 10 \\
\hline 5 & 15 & 0 & 5 & 0 & $\boldsymbol{O}$ & 15 & $\boldsymbol{O}$ & 5 & 10 & 50 \\
\hline 6 & 5 & $\boldsymbol{O}$ & $\boldsymbol{O}$ & 5 & $\boldsymbol{O}$ & 0 & $\boldsymbol{O}$ & 35 & 40 & 15 \\
\hline 7 & 5 & 0 & 15 & 10 & 0 & 5 & $\boldsymbol{O}$ & 30 & 15 & 20 \\
\hline 8 & $\boldsymbol{O}$ & $\boldsymbol{O}$ & 35 & 30 & 15 & $\boldsymbol{O}$ & $\boldsymbol{O}$ & $\boldsymbol{O}$ & 20 & 0 \\
\hline 9 & 0 & 0 & 20 & 25 & 40 & 0 & 0 & 15 & 0 & 0 \\
\hline 10 & 0 & 0 & 25 & 30 & 45 & 0 & 0 & 0 & 0 & 0 \\
\hline \multicolumn{11}{|c|}{$\begin{array}{l}\text { where ZT-the employment of workers; SM-incentive system; } \\
P T-\text { portfolio of technologies; JK-quality; UM- maintenance } \\
\text { of machines; RE - boss-employee relationship; DA-documenta- } \\
\text { tion; } P N-\text { the flow of information; WS - cooperation with cus- } \\
\text { tomers; WD-cooperation with suppliers, cooperators. }\end{array}$} \\
\hline
\end{tabular}

Source: own study.
Data from table 2 shows the assessment of employees' rates for a particular answer. It allowed for determining a percentage structure of significance rates for particular factors.

To assess the validity of the various factors affecting the areas of improving the company, ParetoLorenz diagrams for individual assessments were introduced, which are presented in Fig.3. a)

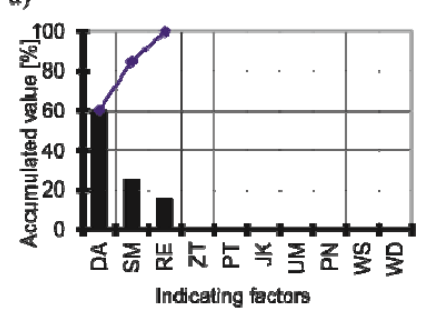

c)

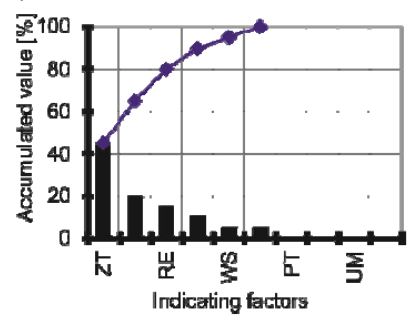

c)

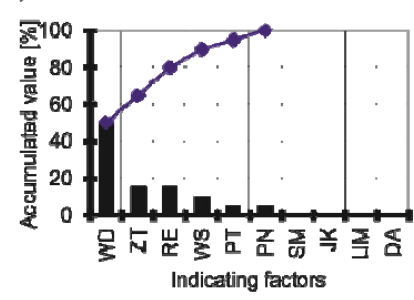

g)

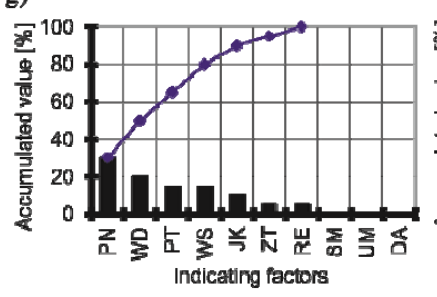

i)

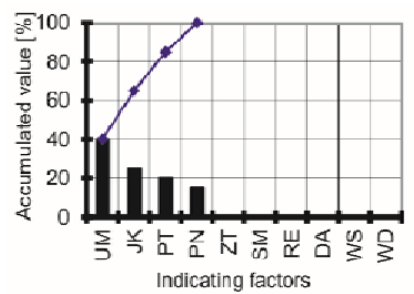

b)

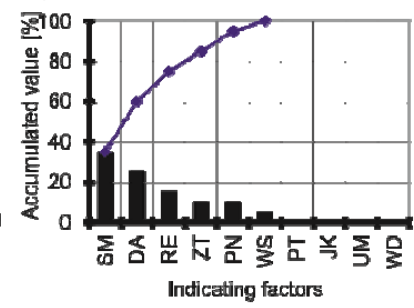

d)

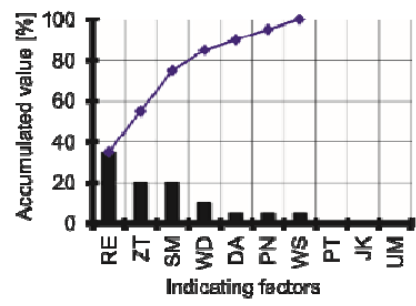

f)

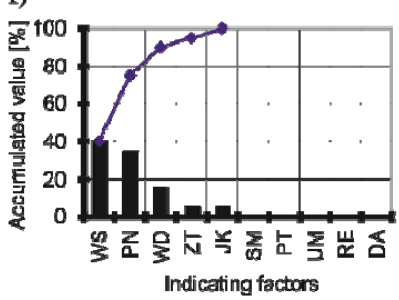

h)

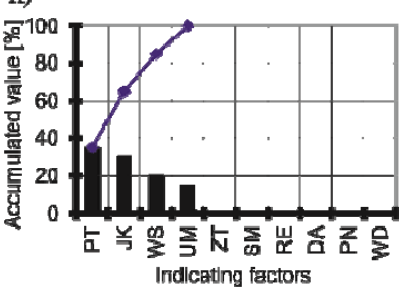

j)

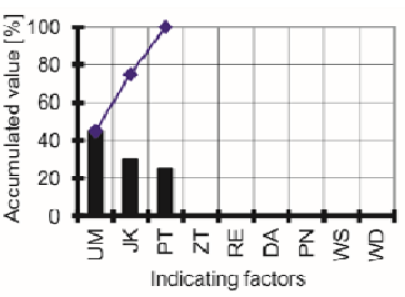

Fig. 3. Principle 14. Pareto-Lorenz diagrams of the factors' importance E8 area for evaluations: a) ,, 1", b) ,,2 ", c) ,,3”, d) ,,4”, e) ,,5”, f) ,,6”, g) ,,7”, h) ,, 8”, i),,9”, j) ,, 10”.

Source: own study. 
Analyzing data presented in Fig. 3, it is easy to acknowledge that the least important areas in terms of improving the quality of products identified by the employees are areas related to documentation, incentive system and employer-employee relationship. In contrast, the areas that are most important from the point of view of production workers were improvement such as maintenance of machines, the quality and portfolio of technologies.

\section{Summary}

The study has been subject to a company operating in the plastics processing industry. The analysis of the study shows that the most important area is the economy of machinery equipment and their proper operation. This is due to the fact that the company is implemented mainly in mass production. The study BOST among production workers showed the greatest need for improvement in the area of maintenance of machines. According to people participating in the production process another important aspect of resource technology reduces the risk of non-conforming products. In order to improve the system particular attention should be paid to technological development and modernization, and proper handling of machinery and equipment. It is important to the employees directly involved in the use of machinery to instill an objective to keep machines at the correct level, conducting ongoing inspections and maintenance, not only when the machine shows a decline in efficiency but also when running without charge, because such conduct will bring more benefits in the form of the company's profit. An important factor also indicated by the employees is the quality of manufactured products.

The least important areas that affect the improvement of the products quality and thus, achieve measurable benefits by the company mentioned are documentation, the incentive system and the factor of employee-supervisor relationship. The most important, in terms of production workers is to improve areas such as machine maintenance, quality and portfolio of technologies.

\section{Literature}

1. BORKOWSKI S. 2012a. Dokumenty zawierajace wymyślony termin (TOYOTARYZM) oraz zawierajace nazwę $i$ strukture opracowanej metody (BOST). Potwierdzenie daty. „AAK” KANCELARIA PATENTOWA s.c. Częstochowa.

2. BORKOWSKI S. 2012b. Toyotaryzm. Wyniki badań BOST. Wydawnictwo Menedżerskie PTM. Warszawa.

3. BoRKOWSKI S. 2012c. Zasady zarządzania Toyoty $w$ pytaniach. Wyniki badań BOST. Wydawnictwo Menedżerskie PTM. Warszawa.

4. BorkOWSKI S., KRYNKE M., INGALDI M. 2012. Quality of Services from the Scope of Decorative Concrete. Chapter 5. Toyotarity. Quality of Services Assessment According to BOST Method. Monography. Editing and Scientific Elaboration Stanisław Borkowski, Manuela Ingaldi. Faculty of Logistics, University of Maribor. Celje s. 52-62.

5. BORKOWSKI S., KRYNKE M., KNOP K. 2012. Evaluation of the Development Concept Factors of a Company from Automotive branch. Chapter 6. Quality Control as Process Improvement Factor. Monography. Editing and Scientific Elaboration Stanisław Borkowski, Manuela Konstanciak. Ofic. Wydaw. Stowarzyszenia Menedżerów Jakości i Produkcji. Częstochowa. s. 84-99.

6. KNOP K., SELEJDAK J. 2009. Implementation of FMEA method to improvement of quality food product. Chapter 12. Quality and Processes Improvement. Monography. Editing and Scientific Elaboration Borkowski S., Czaja P. Endi Miletić. Sisak.

7. MAZUR M., Ulewicz R. 2007. Wykorzystanie metody FMEA dla zapewnienia jakości procesu wytwarzania linki sprzegła samochodowego. Nowe technologie i osiągnięcia w metalurgii i inżynierii materiałowej. VIII Międzynarodowa Konferencja Naukowa. T.1. Częstochowa.

8. UlEWICZ R. 2003. Quality control system in production of the castings from spheroid cast iron, Metalurgija, Volume 42, Issue 1, s. 61-63.

9. Vogt K., KuJAwiŃsKa A.2013. Analiza wpływu wybranych czynników pracy na skuteczność kontroli wzrokowej. Inżynieria Maszyn, R. 18, z. 1, s. 40-51 